\title{
The effects of increasing amounts of milk replacer powder added to whole milk on feed intake and performance in dairy heifers
}

\author{
R. A. Azevedo, ${ }^{*}$ F. S. Machado,† M. M. Campos, $†$ P. M. Furini, ${ }^{*}$ S. R. A. Rufino, ${ }^{*}$ L. G. R. Pereira, $†$ \\ T. R. Tomich, $†$ and S. G. Coelho*1 \\ *Department of Animal Science, School of Veterinary Medicine, Federal University of Minas Gerais, Belo Horizonte, Minas Gerais, \\ 30161-970, Brazil \\ †Embrapa Dairy Cattle, Juiz de Fora, Minas Gerais, 36038-330, Brazil
}

\begin{abstract}
The aim of this study was to evaluate the effects on feed intake, heifer performance, and health of increasing the total solids (TS) content of liquid feed (whole milk) by adding increasing amounts of milk replacer powder during the pre- and postweaning periods. Crossbred Holstein-Gyr heifers $(\mathrm{n}=60)$ were assigned to 1 of 4 treatments ( $\mathrm{n}=15$ per group), which consisted of different TS concentrations: $12.5,15.0,17.5$, and $20.0 \%$ of liquid feed. Heifers received $6 \mathrm{~L}$ of liquid feed per day, divided into 2 equal meals (0800 and $1600 \mathrm{~h}$ ) and provided in buckets, from 5 to $55 \mathrm{~d}$ of age. From 56 to 59 $\mathrm{d}$ of age, the total amount of liquid feed was reduced by half, maintaining only morning feedings. Heifers were weaned at $60 \mathrm{~d}$ and monitored until $90 \mathrm{~d}$ of age. Water and starter were provided ad libitum during the entire experiment. Corn silage was included in the diet during the postweaning period (70 d of age). Feed intake and health scores were evaluated daily. Body weight and body frame development were recorded weekly. Starting at $14 \mathrm{~d}$, ruminal $\mathrm{pH}$ was measured every other week. Laboratory analysis determined that the actual TS contents of the liquid feed were 13.5, 16.1, 18.2, and $20.4 \%$, for the proposed $12.5,15.0,17.5$, and $20.0 \%$ TS treatments, respectively. The osmolality of liquid feed treatments was 265 to $533 \mathrm{mOsm} / \mathrm{L}$. Intake of liquid feed was similar among treatments from 4 wk of age. During the preweaning period, starter intake, fecal score, and days with diarrhea were similar among treatments. Ruminal $\mathrm{pH}$ at weaning averaged 6.2 and was similar among treatments. Increasing concentrations of TS in the liquid feed were associated with linear increases in average daily gain, final body weight, and growth performance, but linear decreases in feed efficiency. During the postweaning period, intake of starter, corn silage,
\end{abstract}

Received September 28, 2015.

Accepted May 1, 2016.

${ }^{1}$ Corresponding author: sandragesteiracoelho@gmail.com and water were similar among treatments, as well as average daily gain and feed efficiency. Final body weight and growth performance during the postweaning period also increased linearly with concentration of TS in liquid feed. Increasing the concentration of TS in liquid feed up to $20.4 \%$ increased performance and body frame development in dairy heifers during the pre- and postweaning periods and had no effects on solid feed intake or health.

Key words: calf, osmolality, performance, total solids

\section{INTRODUCTION}

Restricted milk feeding during the preweaning period is widely used to reduce costs in calf rearing. This practice is also known to stimulate starter intake and promote early rumen development. However, limiting milk consumption, especially during the first month of life, has been challenged by recent research. Kiezebrink et al. (2015) and Yunta et al. (2015) have demonstrated that calves given restricted amounts of liquid feed are unable to ingest sufficient nutrients to ensure satisfactory ADG. In addition, adequate nutrient intake during the preweaning period is essential for calf well-being, health, and future productivity.

Compared with calves fed lower amounts of milk or milk replacer, heifers fed milk ad libitum achieve improved growth rates (Jasper and Weary, 2002); higher volumes of milk (Borderas et al., 2009) or milk replacer (Kmicikewycz et al., 2013; Silper et al., 2014) during the preweaning period with no negative effects on rumen development (Khan et al., 2007; Silper et al., 2014); and better health (Borderas et al., 2009; Hengst et al., 2012; Bach et al., 2013). Recent studies also observed that heifers given higher volumes of liquid feed showed improved immune response postweaning compared with heifers given lower volumes (Ballou, 2012; Ballou et al., 2015). However, despite these advantages, farmers and technicians are reluctant to increase the volume of milk fed to heifers because of increased costs for milk or milk 
replacer, and possible reductions in the amount of milk available for sale (Moore et al., 2009).

Milk is an excellent way of providing high-quality nutrients to heifers, even though it may lead to higher costs than milk replacer. However, different factors, such as lactational stage, nutritional status of the cows, and TS fluctuation of waste milk (Moore et al., 2009) may alter nutrient contents. One way to partially overcome this problem is to add products commonly sold as "balancers," which increase the TS content in the liquid feed without increasing the amount of milk feed (Glosson et al., 2015). Jenny et al. (1982) recommended that calves be fed milk replacer once a day, with a concentration of 10 to $13 \%$ of TS in the liquid feed offered at $8 \%$ of BW, and free access to starter. However, Glosson et al. (2015) observed that higher volumes of pasteurized milk enriched with milk balancer $(17.6 \%$ TS) increased the ADG, BW, and feed efficiency of heifers compared with those fed $3.8 \mathrm{~L} / \mathrm{d}$ of pasteurized milk without milk balancer (12.5\% TS) during the preweaning period.

Moreover, the final osmolality of a liquid feed must be considered when TS are increased. According to McGuirk (2003), the normal serum osmolality in blood is about 280 to $290 \mathrm{mOsm} / \mathrm{kg}$, and milk is an isosmotic food. As liquid feed osmolality increases, gastric emptying becomes faster and more complete, and this can reduce diet digestibility (McGuirk, 2003). In contrast, a delay in gastric emptying may increase nutrient absorption and utilization. Although reference values are not well established, McGuirk (2003) has noted that fluids with an osmolality greater than $600 \mathrm{mOsm} / \mathrm{L}$ should be offered with caution, and they should never be provided when water is not available. According to Glosson et al. (2015), an increase in osmolality resulting from the addition of milk balancer to whole milk can affect water absorption by the intestines, leading to an increase in incidence of diarrhea.

Recommendations for the maximal concentration of TS in liquid feed are still not well established, and further research on the effects of different concentrations of liquid feed TS on calf performance is needed. The objective of this study was to evaluate the effect of increasing the concentration of TS in whole milk on feed intake, performance, body frame development, feed efficiency, and health in heifers during the pre- and postweaning periods by adding milk replacer powder (MRP).

\section{MATERIALS AND METHODS}

Protocols for this study were approved by the ethics committee of Embrapa Dairy Cattle, under protocol n. 06/2014. The experiment was conducted at the Embrapa Dairy Cattle Experimental Farm, located in Coronel Pacheco, Minas Gerais, Brazil.

\section{Animals, Housing, and Treatments}

Holstein $\times$ Gyr crossbred heifers $(\mathrm{n}=60)$ were used; their genetic composition was $5 / 8$ or more Holstein and $3 / 8$ or less Gyr. Heifers were born between April and June 2014 (Brazilian autumn). Dams were vaccinated against clostridial infections (Excell 10, Vencofarma, Londrina, Brazil) at $25 \mathrm{~d}$ prepartum.

At birth, heifers were removed from their dams, weighed and had their umbilical cord immersed in iodine solution $(7 \%)$. Colostrum (3L; > $50 \mathrm{~g} / \mathrm{L}$ of $\operatorname{IgG}$ ) was fed within $6-8 \mathrm{~h}$ after birth. Blood samples were collected via jugular venipuncture within $48 \mathrm{~h}$ after birth. Samples were centrifuged at $800.6 \times g$ for $10 \mathrm{~min}$ to measure total serum protein using a refractometer (Serum protein REF-301, Biocotek, Ningbo, China). Total serum protein was used to assess the quality of the passive transfer of immunity attained by colostrum feeding. We used $5.5 \mathrm{~g} / \mathrm{dL}$ total serum protein as a threshold for good transfer of immunity (McGuirk, 2003). All heifers were housed in individual shelters over tropical grass pasture (Cynodon spp.) throughout the study.

At 2 to $4 \mathrm{~d}$ of age, heifers were fed $6 \mathrm{~L} / \mathrm{d}$ of transition milk divided into 2 equal meals offered at 0800 and $1600 \mathrm{~h}$. At $5 \mathrm{~d}$, heifers were assigned to 1 of 4 treatment groups ( $\mathrm{n}=15$ per group), maintaining a balance of birth month, birth BW, total serum protein, and genetic composition in each group. Treatments consisted of increasing amounts of MRP (Sprayfo Violet SSP, Sloten B. V., Deventer, the Netherlands; Table 1) added to $6 \mathrm{~L} / \mathrm{d}$ of whole milk $(12.6 \pm 0.7 \% \mathrm{TS}$, mean \pm SD; Table 1) to adjust TS to expected concentrations of $12.5,15.0,17.5$, and $20.0 \%$ of liquid feed. The initial TS content in the whole milk was measured daily, immediately after milking and before each feeding, using a Brix refractometer (DD-3 Palm Abbe Digital, Misco, Solon, OH). Brix grade values were converted to TS content using the equation proposed by Moore et al. $(2009)[\mathrm{TS}=0.9984 \times($ Brix refractometer reading $)$ $+2.077]$ and the amount of MRP to be added to the whole milk was adjusted to achieve the desired TS content for each treatment. The MRP was added to the whole milk immediately before it was supplied to the heifers. The time between milking and feeding the heifers was not more than $30 \mathrm{~min}$.

The total volume of treatment $(6 \mathrm{~L} / \mathrm{d})$ was divided into 2 equal meals (0800 and $1600 \mathrm{~h}$ ) and provided to heifers in buckets from 5 to $55 \mathrm{~d}$ of age. At $56 \mathrm{~d}$, the 
Table 1. Nutrient composition (DM basis, \% unless otherwise noted) of whole milk, milk replacer powder (MRP), starter, corn silage, and treatments

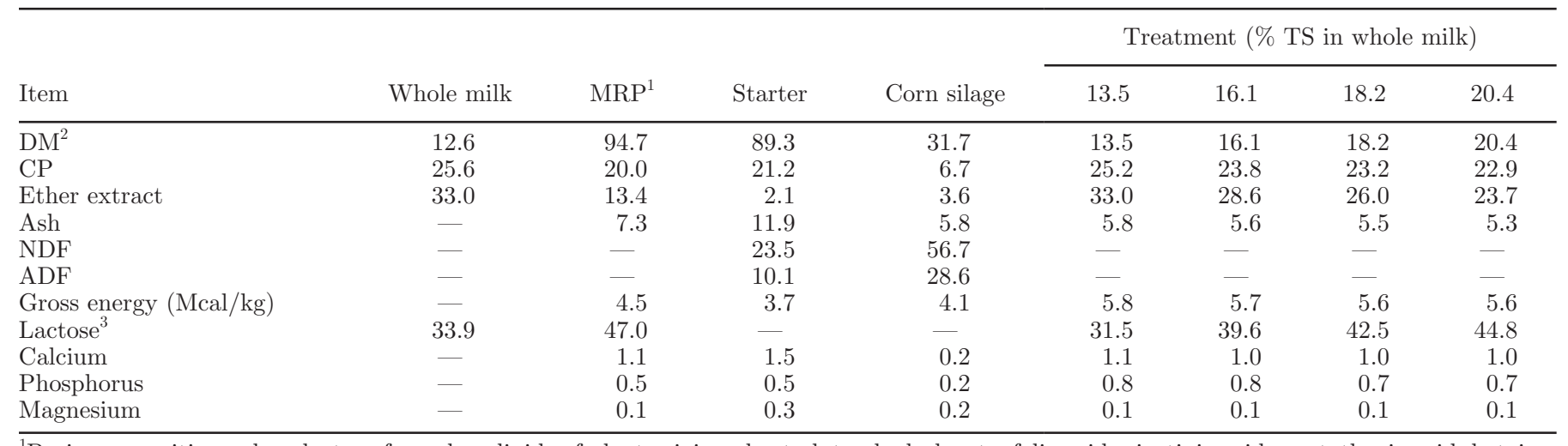

${ }^{1}$ Basic composition: whey, lactose-free whey, lipids of plant origin, wheat gluten hydrolyzate, folic acid, nicotinic acid, pantothenic acid, betaine, biotin, iron oxide, magnesium oxide, zinc oxide, sodium selenite, copper sulfate, manganese sulfate, vitamin $A$, vitamin $B_{1}$, vitamin $B_{12}$, vitamin $\mathrm{B}_{2}$, vitamin $\mathrm{B}_{6}$, vitamin $\mathrm{C}$, vitamin $\mathrm{D}_{3}$, vitamin $\mathrm{E}$, vitamin $\mathrm{K}$, and probiotic additive (Enterococcus faecium and Lactobacillus rhamnosus).

${ }^{2}$ As-fed basis.

${ }^{3}$ Lactose $\%$ of treatments $=100-$ CP $\%$ - ether extract $\%-$ ash $\%-2($ Drackley, 2008).

total volume of liquid feed was reduced by half $(3 \mathrm{~L} / \mathrm{d}$ provided at $0800 \mathrm{~h}$ only) and heifers were weaned at 60 d. Starter (Soylac Rumen 20\% Flocculated, Total Alimentos, Três Corações, Brazil; Table 1) and water were offered ad libitum throughout the experimental period. During the postweaning period, at $70 \mathrm{~d}$, corn silage was included in the diet (Table 1). The amount of starter and corn silage provided was sufficient to result in $10 \%$ orts.

\section{Intake, Performance, and Growth}

Heifers' performance, body frame development, and feed intake were monitored until $90 \mathrm{~d}$ of age. Intake of whole milk and MRP mixture, starter, and water were calculated daily by subtracting refusals from the amounts provided. The total intake of DM, CP, and gross energy from starter and whole milk + MRP were calculated during the preweaning period. During the postweaning period, intake of nutrients, starter, and corn silage were evaluated. Water intake was measured using a portable balance (WH-A04, WeiHeng, Shenzhen, China); no bucket reference was used to evaluate evaporation.

Starting at $5 \mathrm{~d}$ of age, BW, withers height (Teletape, Ketchum Canada Inc., Ottawa, Canada), heart girth, and rump width were measured once a week before morning feeding. Feed efficiency was calculated using the ratio between ADG and total DM intake (Khan et al., 2007). During the preweaning period, we collected rumen fluid samples through an esophageal tube $5 \mathrm{~h}$ after morning feeding at 14, 28, 42, and $56 \mathrm{~d}$ and assessed $\mathrm{pH}$ using a portable potentiometer (DM-2-Digimed,
São Paulo, Brazil). During the postweaning period, samples were collected using the same procedure and timing at 70 and $84 \mathrm{~d}$.

\section{Handling and Health Measurements}

At $8 \mathrm{~d}$ of age, preventive oral treatment against coccidiosis (Baycox Ruminants, Bayer, Leverkusen, Germany) was performed, at a $3 \mathrm{~mL} / 10 \mathrm{~kg}$ of BW. Health and fecal scores were monitored daily by trained farm staff. Fecal scores were graded according to Larson et al. (1977), as follows: 1-normal (firm but not hard); 2-soft (does not hold form, piles but spread slightly); 3-runny (spreads readily to about $6 \mathrm{~mm}$ depth); and 4-watery (liquid consistency, splatters). A heifer was considered to have diarrhea if the fecal score was 3 or 4 .

All heifers were dehorned in the first week after weaning. One heifer (treatment $17.5 \%$ TS) was removed from the study in the last week of the postweaning period due to an accident that led to the fracture of its anterior right leg.

\section{Nutritional Composition Analysis}

Milk samples were collected twice a day (morning and afternoon) and analyzed for TS, CP, and fat content using an infrared analyzer (Bentley model 2000, Bentley Instruments Inc., Chaska, MN; Table 1). Samples from liquid feed treatments were collected daily, composed by month, lyophilized, and analyzed for nutritional composition (AOAC, 1990; Table 1). The osmolality of the liquid feed was measured using an osmometer (Micro-Osmette, Natick, MA). 
Samples of the starter, MRP, and corn silage were collected weekly and composed by month to determine $\mathrm{DM}, \mathrm{CP}$, ether extract, ash, Ca, $\mathrm{P}$, and $\mathrm{Mg}$ according to AOAC (1990). We analyzed NDF and ADF in sequence for the starter and corn silage samples using the method described in Van Soest et al. (1991). We determined gross energy using an adiabatic bomb calorimeter (Parr Instrument Company, Moline, IL).

\section{Statistical Analysis}

Data were analyzed using SAS 9.0 (SAS Institute Inc., Cary, NC). All data collected were summarized and analyzed by period [preweaning (5-59 d) and postweaning (60-90 d)] and by week within each period. Weekly averages of feed intake, performance, body frame development, ruminal $\mathrm{pH}$, and days with diarrhea were analyzed using a repeat-measures mixed model (PROC MIXED), including calf as the random component and treatment, week, and their interaction as fixed components. Differences among treatments were assessed using orthogonal polynomial contrasts to estimate the linear, quadratic, and cubic effects of increasing concentrations of TS in the liquid feed. Fecal score was first pooled by period ( 5 and $59 \mathrm{~d}$ of age), and it was tested as a nonparametric variable using the Kruskal-Wallis test and 95\% confidence intervals for treatment comparisons (PROC NPAR1WAY). We analyzed BW at birth and total serum protein using ANOVA, including treatment as a fixed effect and us- ing a Tukey adjustment for $P$-values. Least squares means for each treatment are reported. The variables BW at birth and total serum protein were considered as covariates. Significance was declared at $P \leq 0.05$.

\section{RESULTS AND DISCUSSION}

The actual concentrations of TS in the whole milk + MRP were 13.5, 16.1, 18.2, and 20.4\% TS (Table 1) for the proposed diets of $12.5,15.0,17.5$, and $20.0 \%$ TS, respectively. The difference between the TS content initially proposed and the values found by laboratory analysis may have occurred because the equation used to convert Brix grade values to TS content was designed based on waste milk samples (Moore et al., 2009), which are different from the whole milk used in this experiment.

Birth weight $(34.5 \pm 4.6 \mathrm{~kg}$; Table 2$)$ and passive transfer of immunity were similar among treatments. We evaluated the passive transfer of immunity based on total serum protein value at $24 \mathrm{~h}$ after colostrum feeding, which averaged $6.8 \pm 1.1,6.9 \pm 1.0,6.1 \pm 0.9$, and $6.8 \pm 1.0 \mathrm{~g} / \mathrm{dL}$ for liquid feeds with $13.5,16.1,18.2$, and $20.4 \%$ TS, respectively. Most of the heifers $(85 \%)$ had total serum protein values above $5.5 \mathrm{~g} / \mathrm{dL}$. Nine heifers had total serum protein values below $5.5 \mathrm{~g} / \mathrm{dL}$, but above $5.2 \mathrm{~g} / \mathrm{dL}(2,1,4$, and 2 heifers belonged to the groups receiving liquid feed with $13.5,16.1,18.2$, and $20.4 \%$ TS, respectively). However, these heifers showed

Table 2. Preweaning feed and water intake, performance, structural body measures, feed efficiency, body frame development, and fecal score of heifers $(\mathrm{n}=60)$ fed different TS contents in whole milk during the preweaning period

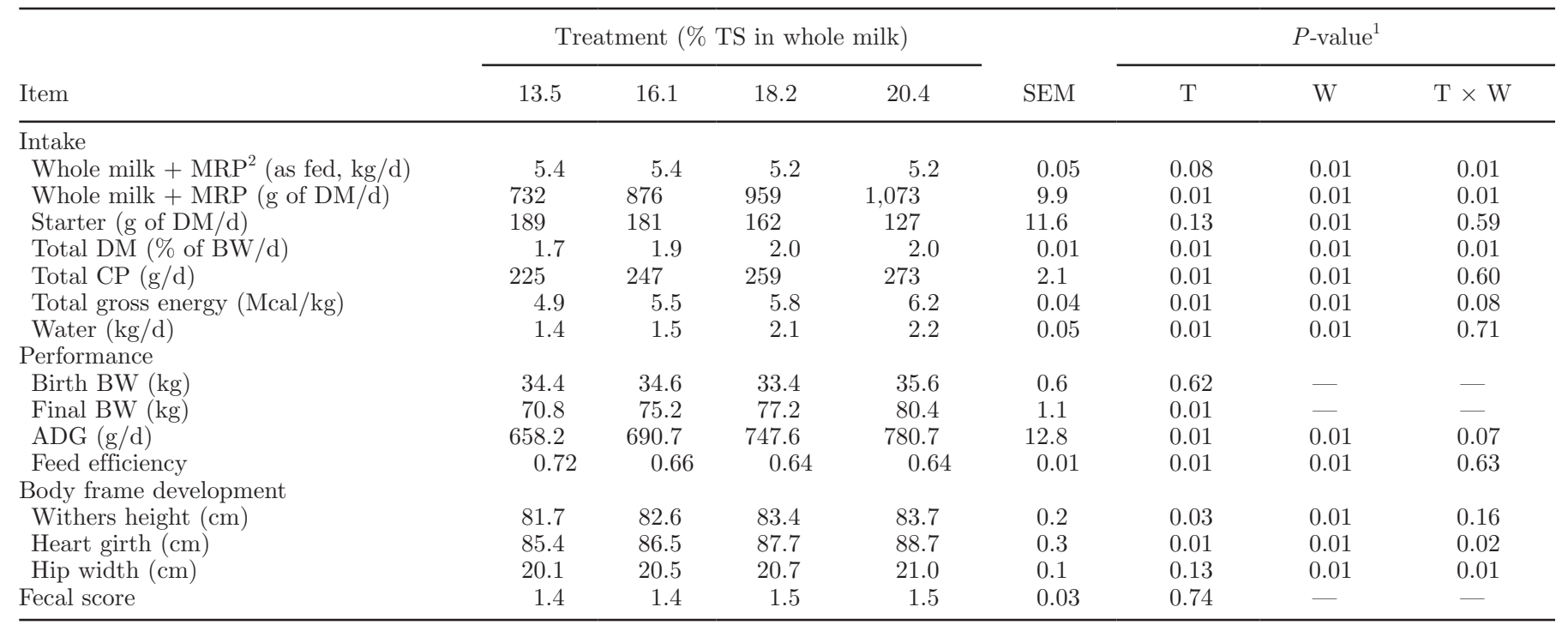

${ }^{1} \mathrm{~T}=$ treatment effect; $\mathrm{W}=$ week effect; $\mathrm{T} \times \mathrm{W}=$ treatment by week interaction.

${ }^{2} \mathrm{MRP}=$ milk replacer powder. 
no signs of illness or changes in feed intake and ADG that could justify the removal of their data.

\section{Preweaning Period}

We observed an interaction $(P=0.01$; Table 2$)$ between treatment and weeks for intake of whole milk $+\operatorname{MRP}(\mathrm{kg} / \mathrm{d})$. During wk 2 and 3, we detected a decrease (linearly, $P=0.01$ ) in intake of whole milk + MRP $(\mathrm{kg} / \mathrm{d})$ as the concentration of TS increased in the liquid feed. After wk 4, we observed a similar intake of whole milk + MRP $(\mathrm{kg} / \mathrm{d})$ among treatments (Figure 1a). However, intake of whole milk + MRP (g of DM/d) increased (linearly, $P=0.01$ ) with concentration of TS in the liquid feed, as initially proposed in the experimental design.

Regardless of the concentration of TS in the liquid feed, heifers were able to ingest all liquid feed provided only after wk 7 (Figure 1a). This indicates a physical limitation to intake capacity in all groups. The observed reduction in feed liquid intake (wk 2 and 3 ) with the increasing concentrations of TS in the liquid feed indicates a chemostatic limitation in the groups with greater amounts of TS (Figure 1a). Silper et al. (2014) also reported that calves were not able to ingest a total volume of 4 or $6 \mathrm{~L} / \mathrm{d}$ of milk replacer $(12.5 \% \mathrm{TS})$ in their first month.

The TS intakes in the liquid feed, measured as $\%$ of BW at birth, were 2.1, 2.5, 2.5, and $2.8 \%$ in wk 2 and $2.2,2.6,2.7$, and $3.0 \%$ in wk 3 , respectively, for liquid feeds with 13.5, 16.1, 18.2, and 20.4\% TS. Kiezebrink et al. (2015) verified an intake of $71 \%$ of the liquid feed during wk 1, and $92 \%$ from wk 2 to 8 , when $8 \mathrm{~L} / \mathrm{d}$ of milk was provided. These values represent a TS intake of 1.8 and $2.3 \%$ TS of BW at birth, respectively. Our results show that increasing the TS content of whole milk is an effective strategy for increasing the amount of nutrients provided to heifers in the first weeks of life. This is also important when considering that the majority of farms provide milk to heifers only twice daily (Jasper and Weary, 2002).

Starter intake (Table 2) was similar among treatments, indicating that a higher intake of TS in liquid feed did not discourage heifers from seeking solid feed. Previous studies showed that increasing TS supplied through higher volumes of liquid feed reduced starter intake (Bach et al., 2013; Kiezebrink et al., 2015; Silva et al., 2015). Glosson et al. (2015) demonstrated that providing $3.8 \mathrm{~L} / \mathrm{d}$ of pasteurized milk enriched with milk balancer (17.6\% TS) reduced starter intake in the same proportion as the greater volumes of liquid feed. In the present study, all heifers consumed an insignificant amount of starter during the first weeks of life and began to increase starter consumption during wk 7 . We observed a substantial increase in starter intake after we reduced the total volume of liquid feed by half ( 3 $\mathrm{L} / \mathrm{d}$ ) in the week before weaning (Figure 1b).

Analysis of total DM intake (liquid feed DM + starter DM) expressed as a percentage of $\mathrm{BW} / \mathrm{d}$ showed an interaction $(P=0.01)$ between treatments and weeks (Table 2). Between wk 2 and 8, total DM intake increased (linearly, $P=0.01$ ) with the concentration of TS. However, in the last week of the preweaning period, total DM intake was similar among treatments (Figure 1c). After the volume of liquid feed offered was reduced by half, animals from the treatment groups with greater amounts of TS in liquid feed were not able to compensate for the reduction in TS by increasing starter intake (Figure 1b) compared with heifers fed $13.5 \%$ TS in liquid feed. As predicted, the total intake of $\mathrm{CP}(\mathrm{g} / \mathrm{d})$ and gross energy (Mcal $/ \mathrm{kg}$ ) increased (linearly, $P=0.01$ ) with the concentration of TS (Table 2).

Heifers fed higher concentrations of TS drank more water (linear increase, $P=0.01$; Table 2). These results corroborate the positive relationship normally observed between total DM intake and water intake (Kertz et al., 1984). Conversely, when a greater volume of milk is offered (and indirectly, a greater amount of TS), there is a negative relationship between DM intake and voluntary water intake (Kiezebrink et al., 2015), because the liquid feed fills part of the need for water. The linear increase of both variables, according to increased amounts of TS in liquid feed, showed that the plateau of this relation is higher than $20.4 \%$ TS.

Ruminal $\mathrm{pH}$ during the preweaning period averaged 6.2 and was similar among treatments. We observed a linear decrease $(P=0.01)$ in ruminal $\mathrm{pH}$ in response the increase in starter intake. The low starter intake (mean $165 \mathrm{~g} \mathrm{DM} / \mathrm{d}$ ) and the presence of fresh forage in the hutches, even in small amounts, may have helped control ruminal $\mathrm{pH}$. At d 42 and 56, heifers presented an average ruminal $\mathrm{pH}$ of 5.9 , close to values described by Duffield et al. (2004) as an indicator of subacute ruminal acidosis in lactating cows. However, in the present study, heifers presented no signs of this disorder, such as tympanism, diarrhea, undigested food in the feces, gas bubbles, or abdominal discomfort (Kleen et al., 2003; Suarez-Mena et al., 2016). According to Suarez-Mena et al. (2015), calves are better able to tolerate lower rumen $\mathrm{pH}$ values than adult animals, and this might explain the potential adaptation of the ruminal epithelium to starter fermentation (Laarman et al., 2012). However, subacute ruminal acidosis in young calves has received scant attention, and the severity of rumen acidosis caused by different factors in dairy calves is not yet clear (Khan et al., 2016). 


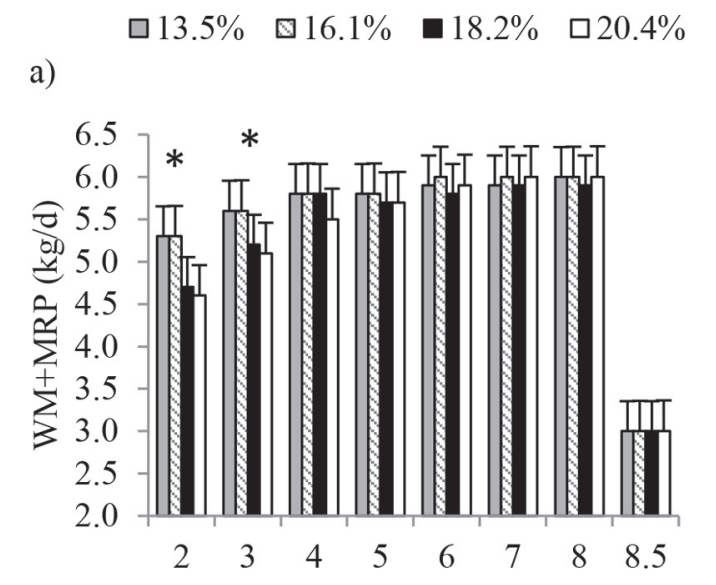

b)
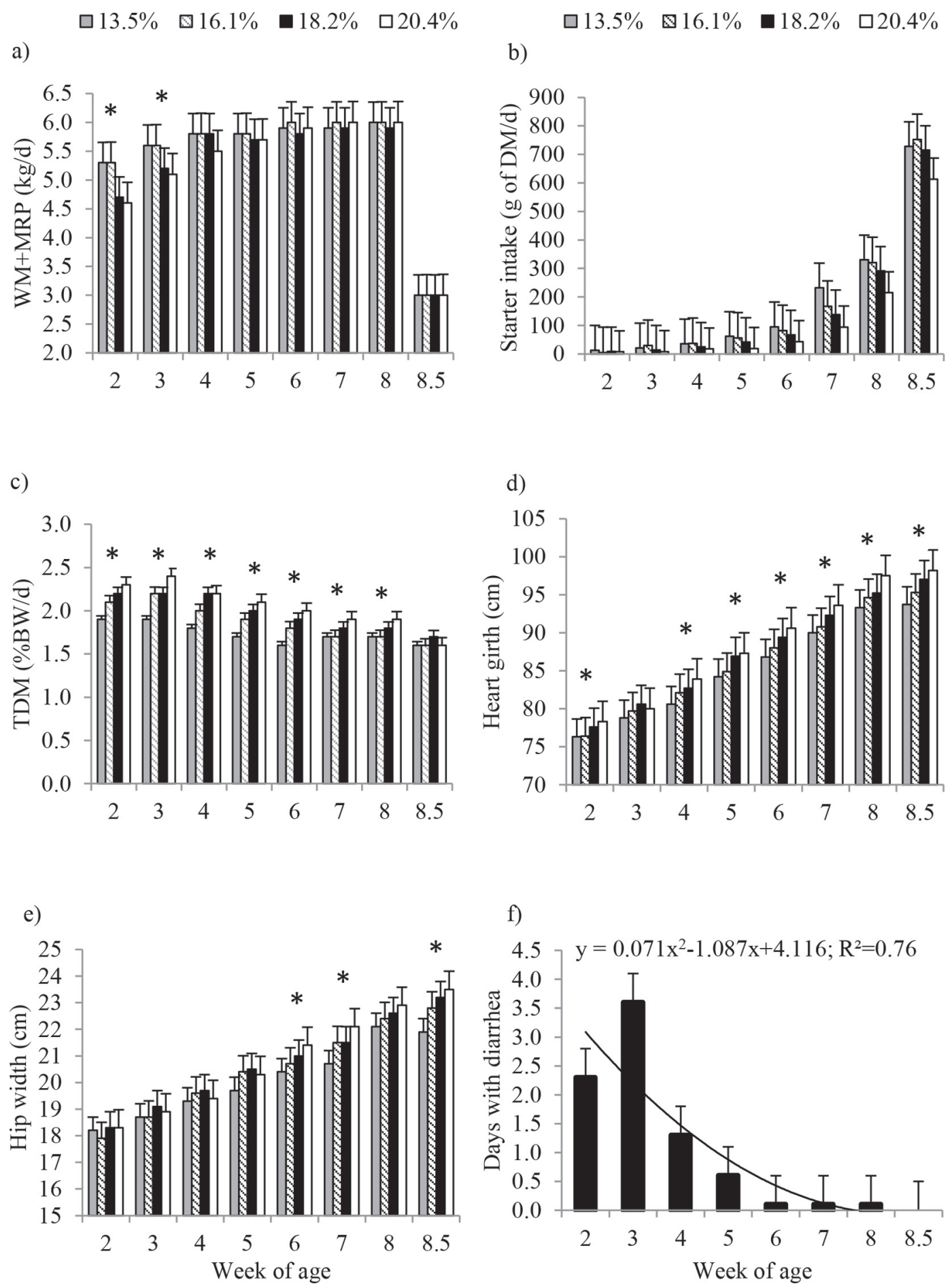

Figure 1. (a) Liquid feed (whole milk + milk replacer powder, WM+MRP; kg/d) intake, (b) starter intake (g of DM/d), (c) total DM intake $(\% \mathrm{BW} / \mathrm{d}),(\mathrm{d})$ heart girth $(\mathrm{cm}),(\mathrm{e})$ hip width $(\mathrm{cm})$, and $(\mathrm{f})$ days with diarrhea of heifers $(\mathrm{n}=60)$ fed different TS contents $(13.5,16.1,18.2$, and $20.4 \%)$ in whole milk during the preweaning period. Error bars represent SE. ${ }^{*}$ Treatment effect $(P \leq 0.05)$ compared with the lowest level of TS fed.

Higher amounts of TS led to an increase (linearly, $P=0.01$ ) in ADG and BW at $60 \mathrm{~d}$ of age (Table 2), similar to results reported by Glosson et al. (2015).
Higher concentrations of TS in the liquid feed led to increased (linearly, $P=0.01$ ) withers height (Table $2)$. We detected interactions $(P=0.01)$ between treat- 
ments and weeks (Table 2) for measurements of heart girth and hip width. Except for wk 3, heart girth increased (linearly, $P=0.01$ ) with the concentration of TS (Figure 1d). During wk 3, 95\% of heifers presented with diarrhea and signs of dehydration, and this could have interfered with girth measurements. We observed differences in hip width only for the sixth, seventh, and final week, when an increase (linearly, $P=0.01$ ) was verified with higher amounts of TS in the liquid feed (Figure 1e).

Body frame development, ADG, and BW at d 60 showed that increasing concentrations of TS favored the development of skeletal and tissue structure during the preweaning period. These results are explained by higher total $\mathrm{CP}$ and gross energy intake $(P=0.01)$ with higher concentrations of TS in the liquid feed (Table 2). According to Blome et al. (2003) and Bartlett et al. (2006), calf growth rate, as well as body protein and water associated with lean tissue, increase when protein is provided in synchrony with energy in the liquid feed. Glosson et al. (2015) did not observe differences in body development as TS content increased up to $17.6 \%$ of the liquid feed. However, the authors noted that similarities in these measurements, combined with higher BW verified in the calves fed a greater volume of enriched milk, suggest a potential addition of muscle and fat. Pettyjohn et al. (1963) suggested that feeding $15 \%$ TS in liquid feed improved performance, body frame development, and more efficient use of nutrients. Jenny et al. (1978) verified a linear increased in ADG when calves were fed with liquid feed containing up to $20 \%$ TS and no starter. In a later study, Jenny et al. (1982) reported similar results when 10 to $13 \%$ TS in liquid feed was used and starter was available to calves. However, in these studies, the increased TS content in liquid feed was exclusively composed of milk replacer and different feed handling procedures were used than in the present study.

Higher amounts of TS decreased (linearly, $P=0.01$ ) feed efficiency (Table 2). To increase the TS content in the liquid feed, MRP was included and the proportion of whole milk was reduced, such that a fixed volume of liquid feed was provided for all treatments $(6 \mathrm{~L} / \mathrm{d})$. Thus, the replacement of nutrients from a dairy source with a non-dairy source may justify the decrease in feed efficiency. However, even with lower efficiency in performance, heifers that received higher amounts of TS were more efficient in terms of body frame development. Other studies also reported greater feed efficiency in calves fed greater volumes of milk (Ballou et al., 2015; Glosson et al., 2015; Silva et al., 2015).

Fecal scores (Table 2) and days with diarrhea (fecal score $\geq 3$ ) were similar among treatments. We observed an average of $1 \mathrm{~d}$ with diarrhea during the preweaning period, and a reduction with quadratic effect across the weeks evaluated (Figure 1f). The incidence of diarrhea for wk 2,3, and 4, regardless of treatment, was 95, 95, and $55 \%$, respectively. According to Jenny et al. (1978), just 1 meal with higher TS content from milk replacer increased the incidence of diarrhea in calves. Calves fed a greater volume of milk, divided in 2 meals, also presented with more days of diarrhea during the preweaning period as the content of TS increased (Ballou et al., 2015; Glosson et al., 2015). The increase in fecal score of calves fed pasteurized milk containing milk balancer can be explained by the higher osmolality of the liquid feed (280-483 mOsm/L), which may affect water absorption in the intestines (Glosson et al., 2015). In the present study, osmolality was $265,351,439$, and 533 $\mathrm{mOsm} / \mathrm{L}$ for the treatments with $13.5,16.1,18.2$, and $20.4 \%$ TS, respectively. However, we observed no differences among treatments for fecal score or days with diarrhea, indicating that the increase in osmolality did not affect the incidence of diarrhea in calves.

It is also important to point out that the MRP used in the present study contained probiotics (Table 1), so the heifers fed more TS also received higher amounts of probiotics in the liquid feed. Therefore, even though we saw no difference in fecal score among treatments (Table 2), variations in the amount of probiotics provided may represent a confounding factor, indicating that further studies are needed to better understand this effect. Signorini et al. (2012) conducted a metaanalysis evaluating the incidence of health issues in young calves and showed that the addition of probiotics to their diet reduced the incidence of diarrhea. This study also found that feeding whole milk containing probiotics further improved the positive effects on fecal score. However, a consensus has not been reached as to whether probiotics may be effective in reducing the prevalence of gastrointestinal diseases in young calves (Signorini et al., 2012). Some studies have reported improvements in the growth performance of calves supplemented with probiotics (Timmerman et al., 2005; Frizzo et al., 2010), but others have found no beneficial effects (Jenny et al., 1991; Abu-Tarboush et al., 1996; Cruywagen et al., 1996). Moreover, Agarwal et al. (2002) found no effect of feeding probiotics on the rumen microbial ecosystem of preweaning calves.

\section{Postweaning Period}

Intake of starter, corn silage, total DM (\% BW/d), total CP (g/d), total gross energy (Mcal kg/d), water, and ruminal $\mathrm{pH}$ were similar among treatments during the postweaning period (Table 3 ). Ruminal $\mathrm{pH}$ 
Table 3. Postweaning feed and water intake, performance, structural body measures, feed efficiency, and body frame development of heifers (n $=60)$ fed different TS contents in whole milk during the preweaning period

\begin{tabular}{|c|c|c|c|c|c|c|c|c|}
\hline \multirow[b]{2}{*}{ Item } & \multicolumn{4}{|c|}{ Treatment (\% TS in whole milk) } & \multirow[b]{2}{*}{ SEM } & \multicolumn{3}{|c|}{$P$-value ${ }^{1}$} \\
\hline & 13.5 & 16.1 & 18.2 & 20.4 & & $\mathrm{~T}$ & $\mathrm{~W}$ & $\mathrm{~T} \times \mathrm{W}$ \\
\hline \multicolumn{9}{|l|}{ Intake } \\
\hline Starter (g of DM/d) & 2,060 & 2,033 & 2,059 & 2,197 & 39.9 & 0.64 & 0.01 & 0.10 \\
\hline Corn silage $(\mathrm{g}$ of $\mathrm{DM} / \mathrm{d})$ & 204 & 176 & 195 & 246 & 11.3 & 0.34 & 0.01 & 0.71 \\
\hline Total DM (\% of BW/d) & 2.5 & 2.3 & 2.3 & 2.4 & 0.03 & 0.32 & 0.01 & 0.26 \\
\hline Total CP $(\mathrm{g} / \mathrm{d})$ & 447 & 437 & 445 & 478 & 8.88 & 0.57 & 0.01 & 0.12 \\
\hline \multicolumn{9}{|l|}{ Performance } \\
\hline Initial BW (kg) & 70.8 & 75.2 & 77.2 & 80.4 & 1.1 & 0.01 & - & - \\
\hline Final BW (kg) & 101.5 & 104.9 & 106.9 & 110.9 & 1.6 & 0.02 & - & - \\
\hline $\operatorname{ADG}(\mathrm{g} / \mathrm{d})$ & $1,036.5$ & 961.3 & 981.5 & $1,022.6$ & 22.8 & 0.69 & 0.01 & 0.83 \\
\hline Feed efficiency & 0.32 & 0.31 & 0.30 & 0.29 & 0.01 & 0.52 & 0.01 & 0.99 \\
\hline \multicolumn{9}{|l|}{ Body frame development } \\
\hline Withers height $(\mathrm{cm})$ & 91.9 & 92.4 & 93.6 & 94.0 & 0.2 & 0.06 & 0.01 & 0.53 \\
\hline
\end{tabular}

${ }^{1} \mathrm{~T}=$ treatment effect; $\mathrm{W}=$ week effect; $\mathrm{T} \times \mathrm{W}=$ treatment by week interaction.

increased $(P=0.01)$ with age; in the first $\mathrm{pH}$ measurement during the postweaning period (70 d of age), the mean $\mathrm{pH}$ was 5.8 and all heifers presented with watery feces containing gas bubbles, indicative of subacute acidosis (Duffield et al., 2004). After corn silage was provided to the heifers at $84 \mathrm{~d}$ of age, the average ruminal $\mathrm{pH}$ increased to 6 , demonstrating the importance of forage in controlling ruminal pH (Castells et al., 2013; Terré et al., 2013, 2015).

During the postweaning period, ADG and feed efficiency were similar among treatments (Table 3). However, the difference in BW among treatment groups observed at the end of the preweaning period was maintained after weaning (Table 3). Ballou et al. (2015) also found that supplying higher volumes of liquid feed to calves promoted greater ADG during preweaning, but 2 weeks after weaning, these animals had a lower ADG than those fed a lower liquid feed volume.

Withers height was similar across treatment groups during the postweaning period, but heart girth and hip width increased (linearly, $P=0.01$ ) with the concentration of TS in the liquid feed (Table 3), indicating that the differences in body frame development observed during the preweaning period were maintained in the postweaning period up to $90 \mathrm{~d}$ of age. Morrison et al. (2009) and Kiezebrink et al. (2015) reported that even when calves presented greater body frame development during the preweaning period, this effect was not maintained after $90 \mathrm{~d}$ of age. These findings show the need for long-term evaluations of heifers fed greater concentrations of TS in liquid feed.

Based on the linear effect of the increasing amounts of TS in the liquid feed on ADG during the prewean- ing period, we can speculate that greater performance could be achieved if heifers were fed liquid feed containing TS concentrations greater than 20.4\%. However, the total intake of liquid feeds was only achieved after wk 7, indicating a plateau for total DM intake. Thus, new strategies of milk feeding with greater amounts of TS need to be evaluated to achieve greater ADG and feed efficiency during the pre- and postweaning periods. Furthermore, economic analyses and the costeffectiveness of different feeding practices should be considered when devising feeding recommendations for sustainable dairy calf production.

\section{CONCLUSIONS}

Increasing total solids in whole milk by the addition of milk replacer powder up to $20.4 \%$ TS is an option for increasing the performance and body frame development of dairy heifers in the pre- and postweaning periods, with no effects on solid feed intake, fecal score, or days with diarrhea.

\section{ACKNOWLEDGMENTS}

The authors thank the Coordenação de Aperfeiçoamento de Pessoal de Nível Superior (CAPES, Brasília, Brazil), Fundação de Amparo à Pesquisa do Estado de Minas Gerais (FAPEMIG, Minas Gerais, Brazil), Conselho Nacional de Desenvolvimento Científico e Tecnológico (CNPq, Brasília, Brazil), and Embrapa Dairy Cattle (Minas Gerais, Brazi) for financial support of this research. We also thank Ana Paula A. Monteiro (University of Calgary. Calgary, Alberta, Canada), 
Eduardo S. Ribeiro (University of Guelph. Guelph, Canada), and Gabriel Gomes (University of Florida) for their time spent correcting this paper.

\section{REFERENCES}

Abu-Tarboush, H. M., M. Y. Al-Asiady, and A. H. K. El-Din. 1996 Evaluation of diet containing lactobacilli on performance, fecal coliform and lactobacilli of young dairy calves. Anim. Feed Sci. Technol. 57:39-49.

Agarwal, N., D. N. Kamra, L. C. Chaudhary, I. Agarwal, A. Sahoo, and N. N. Pathak. 2002. Microbial status and rumen enzyme profile of crossbred calves fed on different microbial feed additives. Lett. Appl. Microbiol. 34:329-336.

AOAC. 1990. Official Methods of Analysis. Vol. I. 15th ed. Association of Official Analytical Chemists, Arlington, VA.

Bach, A., M. Terré, and A. Pinto. 2013. Performance and health responses of dairy calves offered different milk replacer allowances. J. Dairy Sci. 96:7790-7797.

Ballou, M. A. 2012. Immune responses of Holstein and Jersey calves during the preweaning and immediate postweaned periods when fed varying planes of milk replacer. J. Dairy Sci. 95:7319-7330.

Ballou, M. A., D. L. Hanson, C. J. Cobb, B. S. Obeidat, M. D. Sellers, A. R. Pepper-Yowell, J. A. Carrol, T. J. Earleywine, and S. D. Lawhon. 2015. Plane of nutrition influences the performance, innate leukocyte responses, and resistance to an oral Salmonella enterica serotype Typhimurium challenge in Jersey calves. J. Dairy Sci. 98:1972-1982.

Bartlett, K. S., F. K. McKeith, M. J. VandeHaar, G. E. Dahl, and J. K. Drackley. 2006. Growth and body composition of dairy calves fed milk replacers containing different amounts of protein at two feeding rates. J. Anim. Sci. 84:1454-1467.

Blome, R. M., J. K. Drackley, F. K. McKeith, M. F. Hutjens, and G. C. McCoy. 2003. Growth, nutrient utilization, and body composition of dairy calves fed milk replacers containing different amounts of protein. J. Anim. Sci. 81:1641-1655.

Borderas, T. F., A. M. B. de Passillé, and J. Rushen. 2009. Feeding behavior of calves fed small or large amounts of milk. J. Dairy Sci. 92:2843-2852

Borderas, T. F., M. A. G. von Keyserlingk, D. M. Weary, J. Rushen, A. M. de Passillé, and M. E. Van Amburgh. 2009. Feeding behavior of calves fed small or large amounts of milk. J. Dairy Sci. 92:2843-2852.

Castells, L., A. Bach, A. Aris, and M. Terré. 2013. Effects of forage provision to young calves on rumen fermentation and development of the gastrointestinal tract. J. Dairy Sci. 96:5226-5236.

Cruywagen, C. W., I. Jordaan, and L. Venter. 1996. Effect of Lactobacillus acidophilus supplementation of milk replacer on preweaning performance of calves. J. Dairy Sci. 79:483-486.

Drackley, J. K. 2008. Calf nutrition from birth to breeding. Vet. Clin. North Am. Food Anim. Pract. 24:55-86

Duffield, T., J. C. Plaizier, A. Fairfield, R. Bagg, G. Vessie, P. Dick, J. Wilson, J. Arami, and B. McBride. 2004. Comparison of techniques for measurement of rumen $\mathrm{pH}$ in lactating dairy cows. J. Dairy Sci. 87:59-66.

Frizzo, L. S., E. Bertozzi, L. P. Soto, G. Sequeira, R. Rodríguez Armesto, and M. R. Rosmini. 2010. Studies on translocation, acute oral toxicity and intestinal colonization of potentially probiotic lactic acid bacteria administered during calf rearing. Livest. Sci. 128:28-35

Glosson, K. M., B. A. Hopkins, S. P. Washburn, S. Davidson, G. Smith, T. Earleywine, and C. Ma. 2015. Effect of supplementing pasteurized milk balancer products to heat-treated whole milk on the growth and health of dairy calves. J. Dairy Sci. 98:1127-1135.

Hengst, B. A., L. M. Nemec, R. R. Rastani, and T. F. Gressley. 2012. Effect of conventional and intensified milk replacer feeding programs on performance, vaccination response, and neutrophil mRNA levels of Holstein calves. J. Dairy Sci. 95:5182-5193.

Jasper, J., and D. M. Weary. 2002. Effects of ad libitum milk intake on dairy calves. J. Dairy Sci. 85:3054-3058.

Jenny, B. F., S. E. Mills, W. E. Johnston, and G. D. O'Dell. 1978 Effect of fluid intake and dry matter concentration on scours and water intake in calves fed once daily. J. Dairy Sci. 61:765-770.

Jenny, B. F., H. J. Van Dijk, and L. W. Grimes. 1982. Performance of calves fed milk replacer once daily at various fluid intakes and dry matter concentrations. J. Dairy Sci. 65:2345-2350.

Jenny, B. F., H. J. Vandkijk, and J. A. Collins. 1991. Performance and fecal flora of calves fed a Bacillus subtilis concentrate. J. Dairy Sci. 74:1968-1973.

Kertz, A. F., L. F. Reutzel, and J. H. Mahoney. 1984. Ad libitum water intake by neonatal calves and its relationship to calf starter intake, weight gain, feces score, and season. J. Dairy Sci. 67:2964-2969.

Khan, M. A., A. Bach, D. M. Weary, and M. A. G. von Keyserlingk. 2016. Invited review: Transitioning from milk to solid feed in dairy heifers. J. Dairy Sci. 99:885-902.

Khan, M. A., H. J. Lee, W. S. Lee, H. S. Kim, K. S. Ki, T. Y. Hur, G. H. Suh, S. J. Kang, and Y. J. Choi. 2007. Structural growth, rumen development, and metabolic and immune responses of Holstein male calves fed milk through step-down and conventional methods. J. Dairy Sci. 90:3376-3387.

Kiezebrink, D. J., A. M. Edwards, T. C. Wright, J. P. Cant, and V. R. Osborne. 2015. Effect of enhanced whole-milk feeding in calves on subsequent first-lactation performance. J. Dairy Sci. 98:349-356.

Kleen, J. L., G. A. Hooijer, J. Rehage, and J. P. T. M. Noordhuizen 2003. Subacute ruminal acidosis (SARA): A review. J. Vet. Med. A Physiol. Pathol. Clin. Med. 50:406-414.

Kmicikewycz, A. D., D. N. L. da Silva, J. G. Linn, and N. B. Litherland. 2013. Effects of milk replacer program fed 2 or 4 times daily on nutrient intake and calf growth. J. Dairy Sci. 96:1125-1134.

Laarman, A. H., A. L. Ruiz-Sanchez, T. Sugino, L. L. Guan, and M. Oba. 2012. Effects of feeding a calf starter on molecular adaptations in the ruminal epithelium and liver of Holstein dairy calves. J. Dairy Sci. 95:2585-2594.

Larson, L. L., F. G. Owen, J. L. Albright, R. D. Appleman, R. C. Lamb, and L. D. Muller. 1977. Guidelines toward more uniformity in measuring and reporting calf experimental data. J. Dairy Sci. 60:989-991.

McGuirk, S. M. 2003. Solving calf morbidity and mortality problems. Accessed Mar. 10, 2016. http://www.vetmed.wisc.edu/dms/fapm/ fapmtools/8calf/calfmorbid.pdf.

Moore, D. A., J. Taylor, M. L. Hartman, and W. M. Sischo. 2009 Quality assessments of waste milk at a calf ranch. J. Dairy Sci. 92:3503-3509.

Morrison, S. J., H. C. F. Wicks, R. J. Fallon, J. Twigge, L. E. R. Dawson, A. R. G. Wylie, and A. F. Carson. 2009. Effects of feeding level and protein content of milk replacer on the performance of dairy herd replacements. Animal 3:1570-1579.

Pettyjohn, J. D., J. P. Everett Jr., and R. D. Mochrie. 1963. Responses of dairy calves to milk replacer fed at various concentrations. J. Dairy Sci. 46:710-714.

Signorini, M. L., L. P. Soto, M. V. Zbrun, G. J. Sequeira, M. R. Rosmini, and L. S. Frizzo. 2012. Impact of probiotic administration on the health and fecal microbiota of young calves: A meta-analysis of randomized controlled trials of lactic acid bacteria. Res. Vet. Sci. 93:250-258.

Silper, B. F., A. M. Q. Lana, A. U. Carvalho, C. S. Ferreira, A. P. S. Franzoni, J. A. M. Lima, H. M. Saturnino, R. B. Reis, and S. G. Coelho. 2014. Effects of milk replacer feeding strategies on performance, ruminal development, and metabolism of dairy calves. J. Dairy Sci. 97:1016-1025.

Silva, A. L., M. I. Marcondes, E. Detmann, F. S. Machado, S. C. Valadares Filho, A. S. Trece, and J. Dijkstra. 2015. Effects of raw milk and starter feed on intake and body composition of Holstein $\times$ Gyr male calves up to 64 days of age. J. Dairy Sci. 98:2641-2649.

Suarez-Mena, F. X., A. J. Heinrichs, C. M. Jones, T. M. Hill, and J. D. Quigley. 2015. Digestive development in neonatal dairy calves 
with either whole or ground oats in the calf starter. J. Dairy Sci. 98:3417-3431.

Suarez-Mena, F. X., A. J. Heinrichs, C. M. Jones, T. M. Hill, and J. D. Quigley. 2016. Straw particle size in calf starters: Effects on digestive system development and rumen fermentation. J. Dairy Sci. 99:341-353.

Terré, M., L. I. Castells, M. A. Khan, and A. Bach. 2015. Interaction between the physical form of the starter feed and straw provision on growth performance of Holstein calves. J. Dairy Sci. 98:11011109.

Terré, M., E. Pedrals, A. Dalmau, and A. Bach. 2013. What do preweaned and weaned calves need in the diet: A high fiber content or a forage source? J. Dairy Sci. 96:5217-5225.
Timmerman, H. M., L. Mulder, H. Everts, D. C. van Espen, E. van der Wal, G. Klaassen, S. M. G. Rouwers, R. Hartemink, F. M. Rombouts, and A. C. Beynen. 2005. Health and growth of veal calves fed milk replacers with or without probiotics. J. Dairy Sci. 88:2154-2165.

Van Soest, P. J., J. B. Robertson, and B. A. Lewis. 1991. Methods for dietary fiber, neutral detergent fiber, and nonstarch polysaccharides in relation to animal nutrition. J. Dairy Sci. 74:3583-3597.

Yunta, C., M. Terré, and A. Bach. 2015. Short- and medium-term changes in performance and metabolism of dairy calves offered different amounts of milk replacers. Livest. Sci. 181:249-255. 